\title{
Antibiogram and Diversity of Extended-Spectrum Beta-Lactamase Genes in Scavenging Local Chicken in Morogoro Municipality, Tanzania
}

\author{
Emmanuel Odartei Armah $^{1^{*}}$ and Huruma Nelkiwe Tuntufye ${ }^{2}$ \\ ${ }^{1}$ Biomedical and Public Health Research Unit, Water Research Institute, CSIR, Ghana \\ ${ }^{2}$ Department of Microbiology, Parasitology and Immunology, College of Veterinary and \\ Medical Sciences, Sokoine University of Agriculture, \\ Morogoro, Tanzania \\ *Corresponding author
}

\section{A B S T R A C T}

The poultry industry, especially chicken production has in recent times faced a major set-back due to devastating effects of APEC Extended Spectrum Beta-

\begin{tabular}{|l|}
\hline Ke y w or d s \\
ESBL, APEC, \\
CTX-M, TEM, \\
Morogoro \\
\hline Article Info \\
\hline $\begin{array}{l}\text { Accepted: } \\
\text { 20 February } 2020 \\
\text { Available Online: } \\
\text { 10 March } 2020\end{array}$ \\
\hline
\end{tabular}
Lactases (ESBL) producing organisms. This research aimed at investigating antimicrobial susceptibility profile and diversity of ESBL producing avian pathogenic Escherichia coli(APEC) among fecal cloacal swaps of scavenging local chickens based on the various housing systems. The APEC isolates were determined by virulence factor profiling and by Kirby-Baeur disc diffusion, $42 \%$ of the APEC isolates were found to be ESBL producers. Of the ESBL isolates, $87.5 \%$ were resistant to nalidixc acid, $37.5 \%$ were resistant to cefotaxime, Trimethroprim-Sulfamethoxazole, augmentnin and cephalothin, $25 \%$ were resistant to Ceftriaxone whiles no isolate was resistant to Imipenem, gentamycin and ciprofloxacin. On screening, a total of 32 beta-lactamase genes were found amongst these isolates, all of these isolates harbored the blaTEM gene.Semi-intensively kept chickens harbored more ESBL genes and in more diverse forms than the extensively kept ones.

\section{Introduction}

Avian pathogenic Escherichia coli is responsible for the annual million-dollar loss in the poultry industry worldwide. APEC and other Extended spectrum beta-Lactamase (ESBL)-producing organisms pose major health and economic threats to livestock production, especially in the poultry industry
Selective pressure exerted by antimicrobials leads to the spread of multidrug resistance among avian Escherichia coli(Johnson et al., 2004). ESBLs have been widely identified in Escherichia coli(E. coli) from both healthy and diseased animals and hence considered epidemiologically important (Leigue et al., 2013). It was reported that apparently-healthy poultry could harbor multidrug resistance of 
extra-intestinal E. coli (Lima-Filhi et al., 2013). This presents a health risk to the main consumers, the human populace. Needless is to say, the increasing incidences of ESBLinfections among humans is attributable to the contamination of retail chicken by bacteria that carry them (Cohen-Stuart et al., 2012).

Scavenging local chickens makes over $70 \%$ of the entire chicken population in Tanzania (Minga et al., 2001).Ironically, studies on ESBLs have shunned away from these birds, although they stand a high chance of being the main source of transfer to humans than any poultry. Majority of these birds are kept mainly as free-ranged. A few of them, however, are housed as semi-intensive and a far lesser percentage of them are kept entirely intensive. This is hypothesized to have effect on the control of disease amongst them (Fotsa, 2011).

The aim of this research is to access the diversity of ESBL genes in avian pathogenic Escherichia coli amongst scavenging local chickens in selected areas of Morogoro Municipality, Tanzania.

\section{Materials and Methods}

\section{Study area and sample collection}

The Morogoro municipality. It has a total area of about $531.6 \mathrm{~km}^{2}$ and a population growth rate of $4.7 \%$ per annum. The percentage of the populace thatis engaged in livestock keeping and subsistence farmingis 33\% (National Bureau of Statistics, (2011)). The municipal is subdivided 29 administrative wards, out of which six vicinities were randomly selected. These are: Vibandani, Mazimbu, Kididimo, Misufini, Magadu and the farm at the department of Animal Science and Production at the Sokoine University of Agriculture (figure 1). A total of 400 swabs were collected from six different locations in municipality. The swabs were collected and kept in transport media and transferred into the laboratory on ice.

\section{Isolation of Escherichia coli and DNA extraction}

Procedures used were as described in the Bacterial Analytical Manual BAM 2007. The organisms were grown on MacConkey and Blood Agar media media to detect positive Escherichia coli. Samples were suspected to be E.coli based on morphological appearance. The suspected samples were confirmed by biochemical tests.

\section{Virulence factor profiling to detect APEC strains}

The positive E.coli were investigated for various virulence genes by multiplex PCR, with protocol based on Ewers et al., (2007). Isolates that contain four or more virulence genes were considered APEC isolates (Lima-Filho et al., 2013). The virulence genes that were screened include were in 5 categories; Iron Acquisition ( $\mathrm{Chu} A$, Iro $\mathrm{N}$, Irp 2, Iuc D, Sit chr, sit ep.), Serum resistance (Cvi/Cva, Iss, Omp A, Tra t) Adhesins (Pap $C, T s h$ ), Toxins (Ast A, vat) and Invasins (Gim $B$,Ibe $A)$. The procedures were performed in $25 \mu$ lreaction mixture. This includes: $12.5 \mu \mathrm{l}$ ofTaq polymerase (Dream Tag PCR Master mix, Inqaba Biotec East Africa Ltd), $0.5 \mu \mathrm{l}$ of each $100 \mathrm{Mm}$ dNTP, $0.1 \mu \mathrm{l}(100 \mathrm{pmol})$ oligonucleotide primer pair, $6.9 \mu \mathrm{l}$ of nuclease-free water and $4 \mu 1$ of template DNA. Primer concentration is $0.4 \mathrm{M}$. Conditions of the reaction mixtures include: $5 \mathrm{mins}$ at $95^{\circ} \mathrm{C}$ initial denaturation, $94^{\circ} \mathrm{C}$ of denaturation for $30 \mathrm{~s}$, annealing at $56^{\circ} \mathrm{C}$ for $30 \mathrm{~s}$, elongation at $72^{\circ} \mathrm{C}$ for 3 minutes at 25 cycles, a final elongation at $72^{\circ} \mathrm{C}$ for 10 minutes and a hold at $4^{\circ} \mathrm{C}$. List of primers used is shown in the appendix 3 . 
Kirby-Bauer disc diffusion test on APEC strians: to detect potential ESBL producers

The Kirby-Bauer antimicrobial sensitivity test method was used to determine the isolates that were susceptible to cephalosporins and betalactams, potential ESBL producers. However, susceptibility test were carried on other drugs as well, thus a total of ten antimicrobial drugs were used. These include; augmentinin $(30 \mu \mathrm{g})$, imipenem $(10 \mu \mathrm{g})$, cephalothin $(30 \mu \mathrm{g})$, cefotaxime $(30 \mu \mathrm{g})$, ceftazadime $(30 \mu \mathrm{g})$, ceftriaxone $(30 \mu \mathrm{g})$. The zones of inhibition were measured and the resistance was recorded based on Clinical and Laboratory Standards Institute (CLSI).

\section{Double disc synergy test: to confirm of ESBL producers}

As described by Ravi et al.(2011), the double disk synergy was performed on the suspected ESBL producers for confirmation. The disks of ceftazadime $(30 \mu \mathrm{g})$, ceftriaxone $(30 \mu \mathrm{g})$ and cefotaxime $(30 \mu \mathrm{g})$ were place around an augmentin disk $(30 \mu \mathrm{g}), 20 \mathrm{~mm}$ apart, on a Mueller-Hinton Agar plated swabbed with the test isolate. Enhancement of the inhibition zone of the cephalosporin toward the augmentin disc was interpreted as positive for ESBL production (Ravi et al., 2011).

\section{Screening of ESBL genes}

Isolates that were positive for ESBL were screened to know the types of beta-lactamase (bla) genes they harbored. A total of eight samples were screened for the presence of 12 bla genes. The protocol was by Kiiru et al., (2012). The reactions were carried out in a 25 $\mu \mathrm{l}$ reaction volume. This consist of $12.5 \mu \mathrm{l}$ of taq polymerase, $1 \mu \mathrm{l}$ each of the primer sequence, $5.5 \mu 1$ of the Nuclease free water and $5 \mu \mathrm{l}$ of the DNA template. The primer concentration was $0.4 \mathrm{M}$.
The PCR reactions included the following:5 minutes of initial denaturation at $95^{\circ} \mathrm{C}, 94^{\circ} \mathrm{C}$ of denaturation for 30 seconds, annealing for 30 seconds, elongation at $72^{\circ} \mathrm{C}$ for 30 seconds at 30 cycles, a final elongation at $72^{\circ} \mathrm{C}$ for 10 minutes and a hold at $4^{\circ} \mathrm{C}$.The annealing temperatures were different for the different primers. The primers used for this and the corresponding primers sequences, as well as the annealing temperatures have been listed in Appendix 1.

\section{Analysis}

Statistical analysis was done by use of Microsoft excel 2003/7 and Epi. Info. Proportions of various characteristics were tested by use of the chi-square test $\left(\mathrm{x}^{2}\right)$. The threshold for statistical significance was indicated in the table with a $\mathrm{P}<0.05$ reflected statistical significance. In biological analysis; the following software were employed: MEGA 7, Sequencing products were analyzed on the National Committee for Biotechnology Information (NCBI) using the basic alignment search tool BLAST.

\section{Results and Discussion}

\section{Antibiogram of ESBL isolates}

PCR amplification to detect the virulence genes showed that 19 out of 192 samples, (9.8\%) were APEC positive. Thus, these isolate had at least 5 virulence factors, $42 \%$ of the APEC isolates were found to be ESBL producers.

As much as $87.5 \%$ of ESBL isolates were resistant to nalidixc acid, $37.5 \%$ were resistant to cefotaxime, TrimethroprimSulfamethoxazole, augmentnin and cephalothin, $25 \%$ were resistant to Ceftriaxone whiles no isolate was resistant to Imipenem, gentamycin and ciprofloxacin 


\section{Prevalence and diversity of ESBL isolates}

The phenotypically positive ESBL isolates were screened for the presence of twelve betalatamase genes, out of which seven different genes were found to be present in various percentages. The highest was bla TEM which recorded a $100 \%$ prevalence. This was followed by bla OXA-1 with $75 \%$. Then bla CMY-2 group, CTX-M group III, with $62.5 \%$ and $50 \%$ respectively. CTX-M group 1 and bla SHV recorded the least prevalence of $12.5 \%$ each (Table 2). PCR detection of blaCMY-2 gene (758bp) showed in figure 2

Forty percent of the semi-intensive isolates were observed to be multi-drug resistant, while none of the extensively kept isolates were. The former harbored all the various types of genes including CTX-M group I and bla SHV genes which were absent in the later. Each of the CTX-M group IV, III and bla CMY were harbored by $40 \%$ of samples from semi-intensive chicken. In the extensive ones they were harbored by $33.33 \%, 66.67 \%$ and $100 \%$ respectively. Whiles all samples of extensive harbored bla OXA 1, bla TEM and bla CMY-2, they were harbored by $60 \%$, $100 \%$ and $40 \%$ respectively in semi-intensive isolates (Table 3).

PCR products of the APEC isolates were sequenced using the Sanger sequencing method. The sequencing products were blasted on the NCBI website and various samples revealed identities to various genes at different identities as shown below. When blasted the blaSHV gene detected a LEN-2 gene with an identity of $92 \%$ and the bla CTX-M 9 gene detected a CTX-M-15 gene with an identity of $92 \%$. (Table 4)

The blaTEM and CTX-M genes have been observed to be the most abundant ESBL genes as reported by other researchers and seen here (Mshana et al., 2013). In a cross- sectional study to identify ESBL producing Enterobacteriaceae from rectal and cloacae swabs of 600 companion and domestic animals in Mwanza, Tanzania,(Schaumberg et al., 2014), the TEM and CTX-M (specifically CTX-M-15) genes were the most prevalent ESBL genes. In that study, blaTEM was harbored by $60 \%$ of the isolates. In this study, the TEM gene was the highest gene recorded and was harbored by all isolates (Table 2). Their study also revealed that the CTX-M-15 was present among all isolates. The CTX-M15 gene was detected with an identity of $92 \%$ to the CTX-M 9(group IV) gene when blasted (Table 4), in this present study. It is one of the most prevalent variants in the world and are mainly associated with the FII plasmids (Nagano et al., 2009). The CTX-M-15 is related to phylogenetic group B2, a virulent extra-intestinal strain (NCBI-BLAST). Its association with apparently healthy chicken is somewhat alarming.Two years before the Tanzanian study, there was an assessment of the risk of importing ESBL producing Enterobacteriaceae and $S$. aureus through chicken meat in Gabon (Sambo et al., 2015). It was also realized that CTX-M-1 and CTXM-14 were predominant in ESBL E. coli from chicken. In this present study, the CTX-M1, together with other genes in the CTX-M group I was detected by the primer CTX-M1. On the other hand, the CTX-M-14 belonging to CTX-M group IV was detected by the CTX-M914 primer (Table 4). Together, these genes were harbored by $50 \%$ of E. coli in this study (Table 2). In effect, the CTX-M and TEM genes of ESBL are still predominant among E. coli in chicken. The is the most common plasmid mediated AmpC betalactamase (Shaheen et al., (2011). The blaCMY-2 gene is knownto offer strong resistance against oxyimino-cephalosporins (cefotaxime, ceftriaxone and ceftaxidime) and as such, $80 \%$ of isolates harboring this gene showed resistance to the oxyiminocephalosporins (Table 1). Shaheen et al., 
(2011) reported that the blaCMY-gene was widely distributed and exhibited resistance against oxyimino-cephalosporins. Although they employed companion animals (as against chicken in this study) and worked in the United States (as against Africa), similar results could only imply that regardless of location and kind of isolates, CMY-gene exhibits high resistance against oxyiminocephalosporins. On the blast, the blaCMY-2 gene detected an OXY-1 gene with an identity of $92 \%$ (Table.4), which was previously known to be associated Klebsiella oxytoca. (González-López et al., 2009).

The blaSHV- gene was one of the least detected (12.5\%) (Table2). Derivatives of the SHV-1 gene, unlike their projenitor, is known to confer resistance to broad-spectrum penicillinas well asoxyimino-cephalosporins (Peirano et al., 2010). In line with this, the only blaSHV-harbored isolate was resistant to all oxyimino-cephalosporins (Table 1).When blasted the blaSHV gene detected a LEN-2 gene with an identity of $92 \%$ (Table 4). This gene was hitherto known to be only associated to $K$. pneuminiae and does not hydrolyze extended-spectrum cephalosporins (Shayan and Bokaeian, 2015).

Generally, beta-lactamase genes were found to be widely distributed and more diverse among isolates from the semi-intensively kept birds than the extensive ones. Thus, the betalactamase genes thrived better amongst semiintensively kept birds that the extensive ones.

Table.1 Antimicrobial resistance profile of ESBL producers $(n=8)$

\begin{tabular}{|c|c|c|c|c|c|c|}
\hline \multirow[b]{2}{*}{ Antimicrobial } & \multicolumn{2}{|c|}{ Susceptible isolates } & \multicolumn{2}{|c|}{ Intermediate isolates } & \multicolumn{2}{|c|}{ Resistant isolates } \\
\hline & Number & Percent & Number & Percent & Number & Percent \\
\hline CRO $(30 \mu g)$ & 4 & 50 & 2 & 25 & 2 & 25 \\
\hline CTX(30 $\mu \mathrm{g})$ & 1 & 12.5 & 4 & 50 & 3 & 37.5 \\
\hline $\mathrm{CAZ}(30 \mu \mathrm{g})$ & 4 & 50 & 3 & 37.5 & 1 & 12.5 \\
\hline $\mathrm{CN}(10 \mu \mathrm{g})$ & 8 & 100 & 0 & 0 & 0 & 0 \\
\hline STX $(25 \mu g)$ & 5 & 62.5 & 0 & 0 & 3 & 37.5 \\
\hline AUG $(30 \mu g)$ & 5 & 62.5 & 0 & 0 & 3 & 37.5 \\
\hline $\mathbf{N A}(30 \mu \mathrm{g})$ & 1 & 12.5 & 0 & 0 & 7 & 87.5 \\
\hline $\operatorname{CIP}(5 \mu g)$ & 3 & 37.5 & 5 & 62.5 & 0 & 0 \\
\hline $\mathrm{KF}(30 \mu \mathrm{g})$ & 3 & 37.5 & 2 & 25 & 3 & 37.5 \\
\hline IMI $(10 \mu g)$ & 8 & 100 & 0 & 0 & 0 & 0 \\
\hline
\end{tabular}

Note: Antimicrobial resistance profiles of APEC. CRO: ceftriaxone, CTX: cefotaxime, CAZ: ceftazadime, CN: gentamycin, STX: Trimethroprim-Sulfamethoxazole, AUG: augmentin, NA: nalidixic acid, CIP: ciprofloxacin KF: cephalothin, IMI: imipenem. 
Table.2 Prevalence of beta-lactamase genes amongst ESBL producing isolates

\begin{tabular}{|l|l|l|c|}
\hline Primer name & Target gene & Number $(\mathbf{n = 8})$ & Percentage \\
\hline TEM & bla TEM & 8 & 100 \\
\hline CTXM 1 & CTX-M group I & 1 & 12.50 \\
\hline CTXM 914 & CTX-M group IV & 3 & 37.50 \\
\hline CTXM 825 & CTX-M group III & 4 & 50.00 \\
\hline CMY 2 & bla CMY-2 group & 5 & 62.50 \\
\hline OXA 1 & bla OXA-1 & 6 & 75.00 \\
\hline SHV & bla SHV & 1 & 12.50 \\
\hline
\end{tabular}

Note: Among the beta-lactamase genes, the highest recorded was bla TEM, followed by OXA-and CMY-2 while SHV was the least.

Table.3 Occurrence of bla genes among housing systems of scavenging local chicken

\begin{tabular}{|l|l|l|l|l|}
\hline ESBL gene & \multicolumn{2}{|l|}{ Extensive(n=3) } & \multicolumn{2}{l|}{$\begin{array}{l}\text { Semi-Intensive(n=5) } \\
\text { Number }\end{array}$} \\
\hline blaTEM & 3 & Percent & 5 & 100 \\
\hline CTX-M group I & 0 & 0 & 1 & 20 \\
\hline CTX-M group IV & 2 & 33.33 & 2 & 40 \\
\hline CTX-M group III & 1 & 66.67 & 2 & 40 \\
\hline blaCMY- 2 & 3 & 100 & 2 & 40 \\
\hline blaOXA1 & 3 & 100 & 3 & 60 \\
\hline blaSHV & 0 & 0 & 1 & 20 \\
\hline
\end{tabular}

Identity of Bla genes found and local scavenging chicken

Table.4 Description of beta-lactamase genes on basic local alignment sequence tool (BLAST)

\begin{tabular}{|l|l|l|l|l|}
\hline Gene & Housing system & Description gene & Identity & Accession \\
\hline blaOXA 1 & Semi-Intensive & OXA-1 & $99 \%$ & NG 049392.1 \\
\cline { 2 - 5 } blaTEM & Extensive & OXA-1 & $99 \%$ & NG 049392.1 \\
\hline \multirow{2}{*}{ blaCTX-M 9 } & Semi-Intensive & TEM 171 & $99 \%$ & NG 050214.1 \\
\cline { 2 - 5 } & Extensive & TEM 171 & $99 \%$ & NG 050214.1 \\
\hline \multirow{2}{blaCMY-2}{} & Semi-Intensive & CTX-M-15 & $92 \%$ & FJ997866.1 \\
\cline { 2 - 5 } & Extensive & OXY-1-6 & $92 \%$ & NG 049845.1 \\
\hline blaSHV & Semi-Intensive & CMY-71 & $98 \%$ & NG 048859.1 \\
\cline { 2 - 5 } & Extensive & CMY-71 & $98 \%$ & NG 048859.1 \\
\hline
\end{tabular}


Appendix.1 List of Betalactamase Genes

\begin{tabular}{|c|c|c|c|}
\hline \multirow[b]{2}{*}{ Target Gene } & \multicolumn{2}{|c|}{ Screening beta-lactamase genes } & \multirow[b]{2}{*}{ Size } \\
\hline & Primer & 5'-3' sequence & \\
\hline \multirow[t]{2}{*}{ blaTEM } & TEM-F & ATGAGTATTCAACAT TTC CG & \multirow[t]{2}{*}{840} \\
\hline & TEM-R & CCAATGCTTAATCAG TGA GG & \\
\hline \multirow{2}{*}{ blaSHV } & SHV-F & TTCGCCTGTGTATTATCTCCCTG & \multirow[t]{2}{*}{854} \\
\hline & SHV-R & TTAGCGTTGCCAGTGYTCG & \\
\hline \multirow{2}{*}{$\begin{array}{l}\text { blaCTX-M } \\
\text { concensus }\end{array}$} & MA1 & ATGTGCAGYACCAGTAARGTKATGGC & \multirow[t]{2}{*}{593} \\
\hline & MA2 & TGGGTRAARTARGTSACCAGAAYCAGCGG & \\
\hline \multirow[t]{2}{*}{ CTX-M group I } & CTXM1-F3 & GAC GAT GTC ACT GGC TGA GC & \multirow[t]{2}{*}{499} \\
\hline & CTXM1-R2 & AGC CG C CGA CGC TAA TAC A & \\
\hline \multirow[t]{2}{*}{ CTX-M group II } & TOHO1-2 F & GCG ACC TGG TTA ACT ACA ATC C & \multirow[t]{2}{*}{351} \\
\hline & TOHO1-1R & CGG TAG TAT TGC CCT TAA GCC & \\
\hline \multirow[t]{2}{*}{ CTX-M group III } & CTXM825F & CGC TTT GCC ATG TGC AGC ACC & \multirow[t]{2}{*}{307} \\
\hline & CTXM825R & GCT CAG TAC GAT CGA GCC & \\
\hline \multirow[t]{2}{*}{ CTX-M group IV } & CTXM914F & GCT GGA GAA AAG CAG CGG AG & \multirow[t]{2}{*}{474} \\
\hline & CTXM914R & GTA AGC TGA CGC AAC GTC TG & \\
\hline \multirow{2}{*}{$\begin{array}{l}\text { blaCMY } \\
\text { (consensus) }\end{array}$} & CF1 & ATGATGAAAAAATCGTTATGC & \multirow[t]{2}{*}{1200} \\
\hline & $\mathrm{CF} 2$ & TTGCAGCTTTTCAAGAATGCGC & \\
\hline \multirow[t]{2}{*}{ blaCMY-1 group } & CMY-1 F & GTGGTGGATGCCAGCATCC & \multirow[t]{2}{*}{915} \\
\hline & CMY-1R & GGTCGAGCCGGTCTTGTTGAA & \\
\hline \multirow[t]{2}{*}{ blaCMY-2 group } & CMY-2 F & GCACTTAGCCACCTATACGGCAG & \multirow[t]{2}{*}{758} \\
\hline & CMY-2R & GCTTTTCAAGAATGCGCCAGG & \\
\hline \multirow[t]{2}{*}{ blaOXA-1 } & OXA-1 F & ATGAAAAACACAATACATATCAACTTCGC & \multirow[t]{2}{*}{820} \\
\hline & OXA-1R & GTGTGTTTAGAATGGTGATCGCATT & \\
\hline \multirow[t]{2}{*}{ blaOXA-2 } & OXA-2 F & ACGATAGTTGTGGCAGACGAAC & \multirow[t]{2}{*}{602} \\
\hline & OXA-2R & ATYCTGTTTGGCGTATCRATATTC & \\
\hline
\end{tabular}




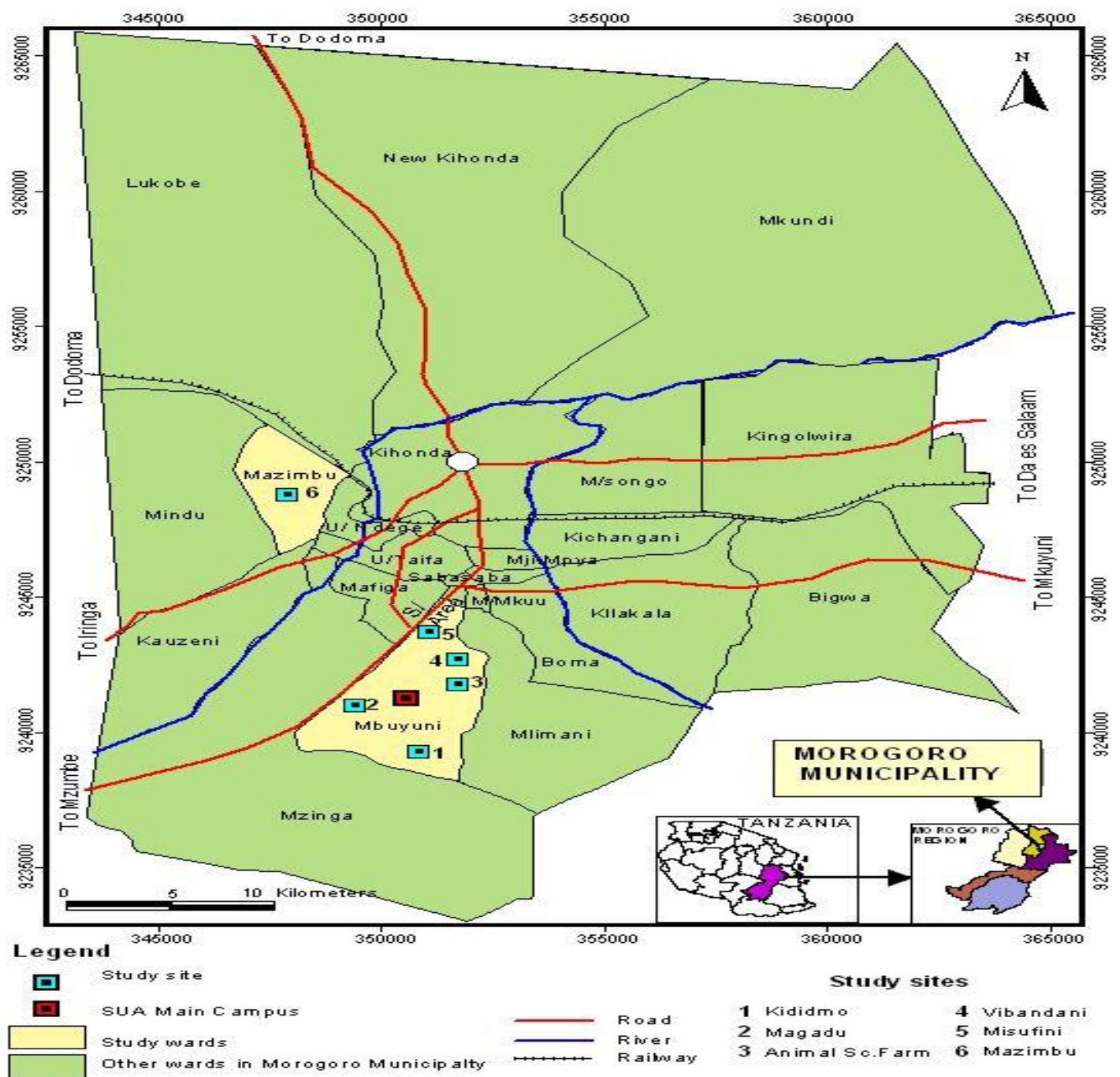

Figure.1 Map of Morogoro municipality wards (map constructed using Arc view GIS)

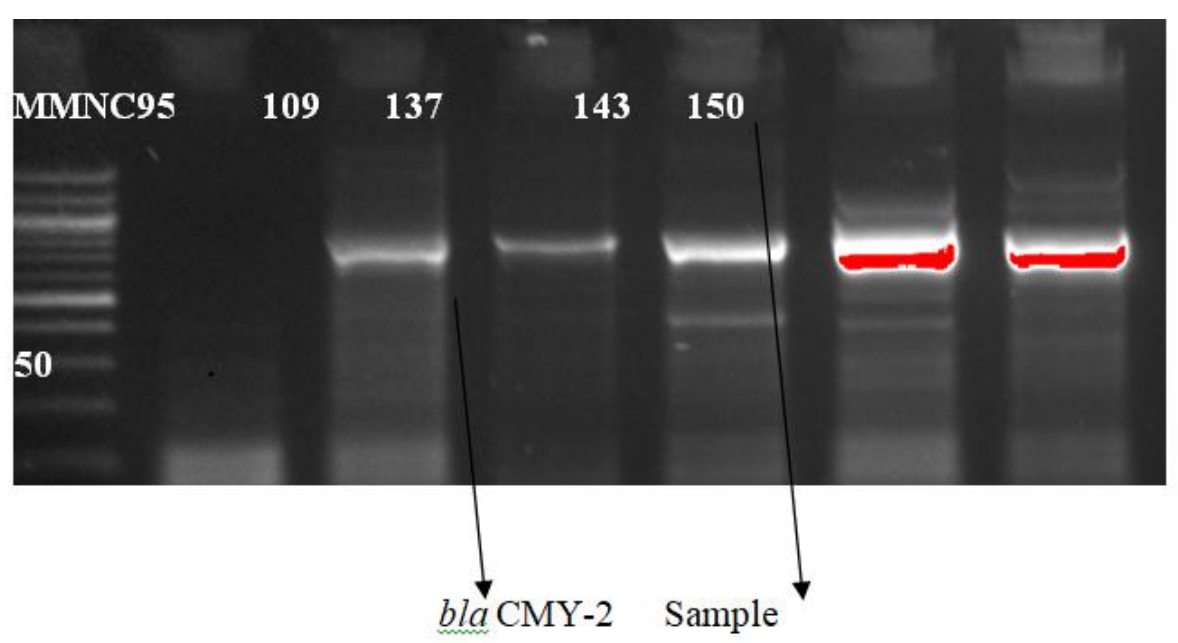

Figure.2 PCR detection of blaCMY-2 gene. Five samples (95, 109, 137, 143 and 150) were positive for the blaCMY-2(758bp); samples.NC is negative control. M is marker (100bp) 
In reviewing the characteristics of scavenging local chickens in Africa, it was stated that, extensively kept chickens have adequate immuno-competence. This is because they roam extensively in the environment for their nutritional requirements and are free from vaccines and antimicrobials (Fotsa, 2011).Semi-intensive system of poultry rearing is characterized by farm in put supplies like drugs, feed and vaccine (Katakweba et al., 2012). In supporting evidence, only 2 out of $3,(66.67 \%)$ of isolates from extensively kept birds were resistant to at least one of the antimicrobials used, whiles all isolates from the birds in the semiintensive $(100 \%)$ showed resistance at various levels. In reference to multi-drug resistance (resistance to more than two categories of drugs), none of the isolates from the extensively kept birds proved to be multi-drug resistant. On the other hand, $40 \%$ of isolates from the semi-intensively kept birds were multi-drug resistant.

\section{Acknowledgements}

The authors are grateful to the Intra-ACP mobility scholarship scheme for the funding of this work. A great appreciation goes to $\mathrm{Mr}$ Mugusi, the chief technologist of the Department of Microbiology, Parasitology and Immunology. College of Veterinary and Medical Sciences, Sokoine University of Agriculture, Morogoro, Tanzania

\section{References}

Bauer, A. W., Kirby, W. M., Sherris, J. C. and Turk, M. (1966). Antibiotic susceptibility testing by a standard single disc method. American Journal of Clinical Pathology 45: 493-496.

Center for Food Safety and Applied Nutrition (2007). United States Food and Drug Administration. Bacteriological Analytical Manual. 80pp.
Clinical Laboratory Standards Institute, (2014). Updates and Recommendations for Antimicrobial Susceptibility Testing and Reporting. Medialab.20pp.

Cohen-Stuart, J., Van den Munckhof, T., Voets, G., Scharringa, J., Fluit, A. and Hall, M. L. (2012). Comparison of ESBL contamination in organic and conventional retail chicken meat. International Journal of Food Microbiology 154(3): 212-214.

Ewers, C., Li, G., Wilking, $\mathrm{H}$ and Wieler, L. H. (2007). Avian pathogenic, uropathogenic and newborn meningitis-causing Escherichia coli: How closely related are they? International journal of medical microbiology 297(3):163-176.

Fotsa, J. C. (2011). Opportunities of poultry breeding programmes for family production in developing countries: The bird for the poor. Proceedings of FAO conference. Rome, Italy, 24January -18February, 2011.126pp.

González-López, J. J., Coelho, A., Larrosa, M. N., Lavilla, S., Bartolomé, R. and Prats, G. (2009). First detection of plasmid-encoded blaOXY $\beta$ Lactamase. Antimicrobial Agents and Chemotherapy 53(7): 3143-3146.

Johnson, J. R., McCabe, J. S., White, D. G., Johnston, B., Kuskowski, M. A. and McDermott, P. (2009). Molecular Analysis of Escherichia coli from retail meats (2002-2004) from the United States National Antimicrobial Resistance Monitoring System. Clinical Infectious Diseases 49(2): 195-201.

Katakweba, A. A. S., Mtambo, M. M. A., Olsen, J. E., and Muhairwa, A. P. (2012). Awareness of human health risks associated with the use of antibiotics among livestock keepers and factors that contribute to selection 
of antibiotic resistance bacteria within livestock in Tanzania. Livestock Research for Rural Development 24(10): 9.

Kiiru, J., Kiriuki, S and Goddeeris, B. M. (2012). Analysis of beta-lactamase phenotype and carriage of selected beta-lactamase genes among Escherichia coli obtained from Kenyan patients during an 18-year peroid. BiodMed Central Microbiology 12(1): 155.

Leigue, L., Moura, R., Aguilar, P. and Lincopan, N. (2013).Current status of extended-spectrum beta-lactamase producing. Enterobacteriaceae in Animlas. Microbial Pathogens and Strategies for Combating them: Science, Technology And Education 3:1600-1607.

Lima-Filho, J. V., Martins, L. V., Ventura, R. F. and Evencio-Neto, J. (2013). Zoonotic potential of multidrug resistant extra-intestinal pathogenic Escherichia coli obtained from healthy poultry carcasses in Salvador, Brazil. Journal of Infectious Diseases 17(1):54-61.

Minga, U., Mtambo, M. and Katule, A. (2001). Improving the health and productivity of the rural chicken in Africa: research and development efforts in Tanzania. Australian Centre for International Agricultural 2(1): 134-139.

Mshana S. E, M. Matee, and M. Rweyemamu, "Antimicrobial resistance in human and animal pathogens in Zambia, Democratic Republic of Congo, Mozambique and Tanzania: an urgent need of a sustainable surveillance system," Annals of Clinical Microbiology and Antimicrobials, vol. 12, no. 1, article 28, 2013.View at: Publisher Site | Google Scholar

Nagano, Y. I., Nagano, N., Wachino, J.,
Ishikawa, K. and Arakawa, Y. (2009). Novel chimeric beta-lactamase CTXM-64, a hybrid of CTX-M-15-like and CTX-M-14 beta-lactamase, found in a Shigella sonnei strain resistant to various oxyimino-cwphalosporins, including ceftazidime. Antimicrobial Agents Chemotherapy 53(1): 69-74.

National Bureau of Statistics, Ministry of Planning, Economic and Empowerment, (2011). Morogoro Regional and District Projections, volume XII, Dar es Salaam, Tanzania. $194 \mathrm{pp}$.

National Committee for Biotechnology Information, Basic Local Alignment Sequence Tool (NCBI-BLAST)

Peirano, G. and Pitout, J. D. D. (2010). Molecular epidemiology of Escherichia coli producing CTX-M beta-lactamase: the worldwide emergence of clone ST131 O25:H4. International Journal of Antimicrobial Agents 35(4): 316-321.

Ravi, S. G., Namratha, W. N., Krishna, B. V. S., Asha, B. P. and Chandrasekhar, M. R. (2011). Comparison of disc diffusion methods for the detection of extended-spectrum beta lactamaseproducing Enterobacteriaceae. Journal of Laboratory Physician 3(1): 33-36.

Sambo, E., Bettridge, J., Dessie, T., Amare, A., Habte, T., Wigley, P. and Christley, R. M. (2015). Participatory evaluation of chicken health and production constraints in Ethiopia. Preventive Veterinary Medicine 118(1): 117-127.

Schaumburg, F., Alabi, A. S., Frielinghaus, L., Grobusch, M. P., Kock, R., Becker, K., Issifou, S., Kremsner, P. G., Peters, G. and Mellmann, A. (2014). The risk to import ESBLproducing Enterobacteriaceae and Staphylococcus aureus through chicken meat trade in Gabon. BMC 
Microbiol 14: 286pp.

Shaheen, B. W., Nayak, R., Foley, S. L., Kweon, O., Deck, J., Park, M., Rafii, F. and Boothe, D. M. (2011). Molecular characterization of resistance to extended-spectrum cephalosporins in clinical Escherichia coli isolates from companion animals in the United States. Antimicrobial Agents and Chemotherapy 55(12): 5666-5677.
Shayan, S. and Bokaeian, M. (2015). Detection of ESBL- and AmpCproducing E.coli isolates from urinary tract infections. Advanced Biomedical Research 4: 220.

Tamura, K., Stecher, G., Peterson, D., Filipski, A.,Sudir, K. (2013) MEGA: Molecular Evolutonary Genetics Analysis version 7.0. Molecular Biology and Evolution: 302725-2729.

\section{How to cite this article:}

Emmanuel Odartei Armah and Huruma Nelkiwe Tuntufye. 2020. Antibiogram and Diversity of Extended-Spectrum Beta-Lactamase Genes in Scavenging Local Chicken in Morogoro Municipality, Tanzania. Int.J.Curr.Microbiol.App.Sci. 9(03): 2699-2709.

doi: https://doi.org/10.20546/ijcmas.2020.903.308 